\title{
KECERDASAN MENGGALI INFOMASI POLITIK DI MEDIA DIGITAL
}

\author{
Salman $^{1} \&$ Syaifuddin ${ }^{2}$ \\ Institut Teknologi dan Bisnis Kalbis
}

\begin{abstract}
This study aims to determine people's understanding of information and political messages that are scattered in the digital world. The development of digital technology has brought about very significant changes in the world of communication today, in connection with information obtained by the public. The spread of information on digital media cannot be dammed, any information can be obtained easily, anyone can access that information without any limitations. The information is presented from very simple to complex, from educating information to information that spreads hatred easily available. This research use desciptive qualitative approach. The results of this study indicate that there is still a very low ability of the community to choose and distinguish between correct political information and false information or "hoaxes". The audience thinks, every information that is available is useful information, although sometimes the information is false information or "hoaxes".
\end{abstract}

Keywords: media literacy, information technology, digital media, hoaxes

\begin{abstract}
Abstrak
Penelitian ini bertujuan untuk mengetahui pemahaman masyarakat terhadap informasi dan pesan politik yang bertebaran dalam dunia digital. Perkembangan teknologi digital membawa perubahan yang sangat siginifikan dalam dunia komunikasi saat ini, sehubungan dengan informasi didapat masyarakat. Tersebarnya informasi pada media digital tidak dapat dibendung, informasi apapun dapat diperoleh dengan mudah, siapapun bisa mengakses informasi tersebut tanpa ada batasan. Informasi yang tersajipun dari yang sangat sederhana sampai yang sanggat komplek, dari informasi yang mendidik sampai informasi yang menyebar kebencian gampang didapatkan. Pendekatan dalam penelitian ini menggunakan pendekatan deskriptif kualitatif. Hasil dari penelitian ini menunjukkan masih sangat rendahnya kemampuan masyarakat dalam memilih dan membedakan antara informasi yang benar dan informasi yang palsu atau "hoax". Khalayak beranggapan setiap informasi yang ada merupakan informasi yang berguna, walaupun kadangkadang informasi tersebut adalah informasi bohong atau "hoax".
\end{abstract}

Kata kunci: literasi media, teknologi informasi, media digital, hoax

\section{PENDAHULUAN}

Jelang pelaksanaan pemilihan umum legislatif dan presiden tahun 2019, informasi dan pesan politik membanjiri media saat ini, pesan-pesan politik

\footnotetext{
${ }^{1}$ Salman. Email: salman.naning@kalbis.ac.id

${ }^{2}$ Syaifuddin. Email: syaifuddin.sayuti@kalbis.ac.id
} 
disajikan sedemikian rupa bertujuan memberikan informasi kepada khalayaknya. Pesan dibingkai (framing) oleh komunikator untuk tujuan tertentu, pesan yang disajikan disesuaikan berdasarkan keinginan komunikator. Disamping itu pemilihan tanda (sign) dalam bentuk kata, gambar, simbol. Pesan yang disajikan juga disesuaikan dengan keinginan dari komunikator yang seakan-akan apa yang disajikan sesuai dengan realitas yang ada. Tujuannya adalah agar setiap pesan yang disajikan dapat menarik sebanyak mungkin khalayak, selanjutnya pesan tersebut disajikan kembali pada media digital, media digital merupakan media berbasis teknologi informasi.

Perkembangan teknologi informasi dan komunikasi yang sangat cepat, menyebabkan perubahan yang sangat pesat juga pada masyarakat, khususnya generasi millenial yang memang dilahirkan pada era digital. Perubahan masyarakat tersebut diikuti dengan perubahan perilaku, dengan menggunakan teknologi menyebabkan mengalirnya segala macam arus informasi di masyakarat itu sendiri. Informasi yang tersebar ada yang merupakan informasi bermanfaat, baik menambah wawasan penerimanya maupun hiburan yang banyak ditemukan di dunia digital saat ini.

Teknologi digital khususnya internet memungkinkan transformasi elektronik, menghasilkan media baru yang mampu menghubungkan individu di seluruh dunia. Masyarakat di dunia saat ini dapat saling berinteraksi, saling berbagi informasi secara interaktif. Media baru yang dilahirkan dari internet adalah media sosial, melalui media sosial masyarakat dapat saling berhubung satu sama lain, dengan berbagai macam karakteristik yang ada. Media sosial lebih bersifat interaktif dibanding dengan media konvensial seperti majalah, koran, radio maupun televisi. Melalui media sosial, masyarakat dapat berkomunikasi dan beriteraksi dengan orang lain, melalui komunikasi verbal maupun secara non verbal kepada orang lain tanpa dibatasi oleh jarak dan waktu.

Istilah media sosial dan Web 2.0 yang dimulai pada tahun 2005 merupakan penanda platform World Wide Web (WWW) pada jaringan sosial, seperti : Facebook, Linkedln), blog seperti Wordpress, Wikipedia, microblogging (Twitter, Weibo), Youtube. Dalam media Sosial, pengguna dapat membuat dan mereproduksi konten, profil yang berisi data pribadi, hubungan sosial, mempengaruhi komunikasi dan komunitas.

Menurut Nasrullah secara sederhana media sosial dijelaskan sebagai alat komunikasi (Laughey,2007; McQuail, 2003). Pengertian media sosial ini cenderung lebih dekat terhadap sifatnya yang massa karena terlihat dari berbagai teori yang muncul dalam komunikasi massa. Namun, semua definisi yang ada memiliki kecendrungan yang sama bahwa ketika disebutkan kata "media", yang 
muncul bersamaan dengan itu adalah sarana disertai dengan teknologi (Nasrullah, 2015:3)

Media sosial memiliki karakteristik khusus yang tidak dimiliki oleh berbapa jenis media siber lainnya. Ada batasan-batasan dan ciri khusus tertentu yang hanya dimiliki oleh media sosial dibanding dengan media lainnya. Salah satunya adalah media sosial beranjak dari pemahaman bagaimana media tersebut digunakan sebagai sarana sosial di dunia virtual. Pada akhirnya bagaimana karakteristik media sosial itu bisa dipergunakan untuk bidang seperti jurnalisme, hubungan masyarakat, pemasaran, politik (Nasrullah, 2015:15). Adapun karakteristik media sosial sebagai berikut : (1). Jaringan; (2). Informasi; (3). Arsip; (4). Interaksi; (5). Simulasi sosial; (6). Konten; (7). Penyebaran.

Jaringan (Network). Karakter media sosial membentuk jaringan diantara penggunanya. Kehadiran media sosial memberikan medium bagi pengguna untuk terhubung secara mekanisme teknologi. Jaringan yang terbentuk antar pengguna ini pada akhirnya membentuk komunikasi atau masyarakat yang kemudian memunculkan nilai-nilai dalam teori sosial.

Komunitas yang terbentuk dari jaringan masyarakat menjadi komoditas informasi yang dikonsumsi oleh pengguna. Komoditas tersebut pada dasarnya merupakan komoditas yang diproduksi dan distribusi antar pengguna media sosial tersebut. Informasi yang tersebat dapat berupa arsip yang dapat diakses kapan pun. Bagi pengguna media sosial arsip menjadi sebuah karakter yang menjelaskan bahwa informasi tersimpan dan biasa diakses melalui media apa pun, merupakan kekuatan media sosial sebagai bagian dari media digital yang tidak berdasarkan jaringan atau informasi semata, tetapi juga memiliki arsip dan arsip mengubah cara menghasilkan, mengakses, hingga mayimpan informasi.

Informasi di media sosial menyebabkan terjadinya interaksi antar sesama pengguna. Sederhananya, interaksi yang terjadi di media sosial seperti mengomentari, mempromosikan atau memberikan tanda pada yang dipublikasikan seperti foto, video ataupun pesan-pesan yang memiliki makna dan memberikan motivasi bagi penggunanya. Media sosial tidak lagi menampilkan realitas, tetapi sudah menjadi realitas tersendiri, bahkan apa yang ada di media lebih nyata dari realitas itu sendiri. Realitas media merupakan hasil proses simulasi, dimana representasi yang ada di media telah diproduksi dan direproduksi oleh media menjadi realitas sendiri.

Produksi dan reproduksi konten oleh pengguna merupakan karakteristik media sosial lainnya, karakter ini menunjukkan bahwa konten media sosial sepenuhnya milik dan berdasarkan kontribusi pengguna atau pemilik akun. Pemilik akun media sosial merupakan penyebar informasi, penyebaran informasi merupakan karakteristik lain dari media sosial. Karakter ini tidak hanva Jurnal Avant Garde 6, No. 2, Desember 2018 
menghasilkan konten yang dibangun dari dan dikonsumsi oleh penggunanya, tetapi juga didistribusikan sekaligus dikembangkan oleh penggunanya terkait informasi tersebut.

Informasi yang disebarkan atau pun diterima pengguna, ada informasi yang hanya menyebarkan kebencian, kebohongan atau dari yang sifatnya iseng menjadi merugikan masyarakat itu sendiri. Untuk menghindari hal tersebut tentunya masyarakat harus mengerti dan paham akan media itu sendiri. informasi yang terdapat pada media, baik media konvensional maupun media digital tentunya dihasilkan melalui proses dan sesuai dengan kepentingan. Agar masyarakat tidak salah menerima informasi masyarakat harus melek media atau literasi media, sehingga mereka mampu memilih informasi yang benar-benar bermanfaat.

Berdasarkan kajian yang dilakukan oleh Feodorov, Bajkiewicz (2003) melakukan kajian atas sejumlah dokumen penyelenggaraan pendidikan melekmedia yang diselenggarakan sejumlah lembaga. Bajkeiewicz melakukan identifikasi tujuan pendidikan melek media ini kepada para penyelenggara pendidikan. Hasil kajiannya menemukan tujuan pendidikan media pada dimensi individual, kreatif dan sosial-politik, seperti yang dikemukakan dalam tabel berikut:(Iriantara, 2009:24).

Tabel 1. Tujuan Literasi Media

\begin{tabular}{|c|c|c|c|}
\hline \multirow[t]{2}{*}{ No } & \multicolumn{3}{|c|}{ Dimensi } \\
\hline & Individual & Kreatif & Sosial/Politik \\
\hline 1 & $\begin{array}{l}\text { Mengembangkan } \\
\text { Pemikiran kritis }\end{array}$ & $\begin{array}{l}\text { Memahami sejarah, } \\
\text { kreativitas, permanfaatan } \\
\text { dan evaluasi atas media } \\
\text { massa sebagai praktik } \\
\text { kesenian }\end{array}$ & $\begin{array}{l}\text { Menyiapkan diri } \\
\text { menjadi warga } \\
\text { negara demokratis } \\
\text { yang memiliki } \\
\text { informasi }\end{array}$ \\
\hline 2 & $\begin{array}{l}\text { Mengembangkan } \\
\text { kesadaran kritis atas media }\end{array}$ & $\begin{array}{l}\text { Mengenali struktur dan } \\
\text { pesan media massa }\end{array}$ & $\begin{array}{l}\text { Dipergunakan } \\
\text { untuk advokasi } \\
\text { sosial }\end{array}$ \\
\hline 3 & $\begin{array}{l}\text { Mengembangkan "otonomi } \\
\text { kritis" }\end{array}$ & $\begin{array}{l}\text { Memiliki struktur dan } \\
\text { pesan media massa }\end{array}$ & $\begin{array}{lr}\text { Mengubah } & \text { relasi } \\
\text { kekuasaan } & \text { yagn } \\
\text { mapan } & \text { antara } \\
\text { guru-murid } & \\
\end{array}$ \\
\hline 4 & $\begin{array}{l}\text { Menyandi-balik, } \\
\text { mengevaluasi, } \\
\text { menganalisis dan } \\
\text { memproduksi media }\end{array}$ & $\begin{array}{l}\text { Terlibat aktif dalam } \\
\text { proses produksi }\end{array}$ & $\begin{array}{l}\text { Mengenali } \\
\text { informasi sebagai } \\
\text { landasan } \\
\text { penyusunan pesan }\end{array}$ \\
\hline 5 & $\begin{array}{l}\text { Memiliki makna, memirsa } \\
\text { secara kritis, mengkaji } \\
\text { authorship dan penalaran }\end{array}$ & & \\
\hline
\end{tabular}

Sumber: Bajkiewicz (dalam Iriantara, 2009:25). 
Menurut Varis, ada tiga perkara penting yang perlu kita perhatikan sejalan dengan perkembangan literasi ini. Ketiga perkara tersebut adalah (1) kita harus bisa memahami proses belajar seperti apa yang bisa membuat orang literate, selain itu juga harus bisa memahami seperti apa kompetensi - kompetensi komunikasi dan keterampilan media yang bermakna dan penting pada masyarakat informasi; (2) kita perlu menganalisis peningkatan jumlah neo-iliterasi; dan (3) kita perlu mengkaji seperti apa keterampilan yang harus diberikan kepada masyarakat saat ini seperti halnya kita dulu menerima pembelajaran keterampilan membaca dan menulis (Iriantara, 2009: 5). Secara lebih utuh, Raffeti (2003) membandingkan tiga jenis literasi sebagai berikut:

Table 2. Jenis-jenis Literasi

\begin{tabular}{|c|c|}
\hline Jenis & Definis \\
\hline \multirow[t]{3}{*}{$\begin{array}{l}\text { Literasi Alfabetis atau } \\
\text { Literasi Berbasis Teks }\end{array}$} & $\begin{array}{l}\text { 1. Literasi naratif, yakni kemampuan } \\
\text { belajar untuk membaca (khususnya, } \\
\text { prosa) }\end{array}$ \\
\hline & 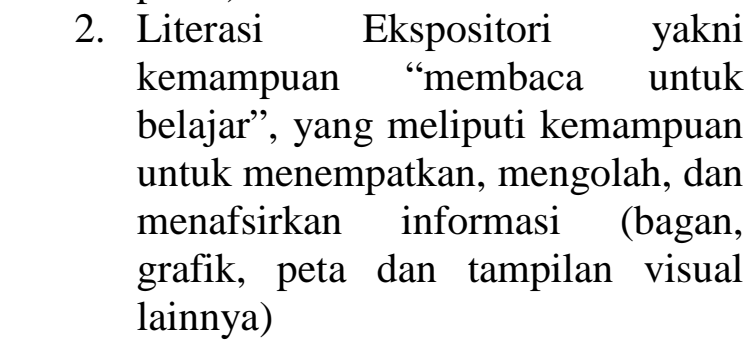 \\
\hline & $\begin{array}{l}\text { 3. Literasi Dokumen yakni } \\
\text { kemampuan "membaca untuk } \\
\text { melakukan", yang mengandung } \\
\text { penafsiran dan penerapan informasi } \\
\text { untuk tujuan-tujuan khusus (sajian } \\
\text { statistik dan bentuk-bentuk non- } \\
\text { tradisional lainnya) }\end{array}$ \\
\hline Literasi Representasional & $\begin{array}{l}\text { Kemampuan memahami bagaimana makna } \\
\text { dibuat dengan menganalisis informasi }\end{array}$ \\
\hline Literasi Perkakas & $\begin{array}{l}\text { Kemampuan untuk menggunakan teknologi } \\
\text { dan komputer untuk belajar: } \\
\text { 1. Dekoratif (apa) } \\
\text { 2. Prosedural (bagaimana), dan } \\
\text { 3. Kondisional (kapan, di mana, } \\
\text { mengapa dan dalam kondisi apa) }\end{array}$ \\
\hline
\end{tabular}


Sumber : Raffety (dalam Iriantara, 2009:7)

Dari jenis-jenis literasi tersebut, melek media digital menjadi sangat penting bagi khalayak saat ini. Dalam dunia digital literasi tidak hanya sebatas alfabetis dan representasional saja, akan tetapi juga harus memahami literasi perkakas yang sangat erat kaitannya dengan teknologi dan peralatan yang digunakan. Media digital tidak terlepas dari teknologi yang melekat padanya, hal ini sangat diperlukan karena melek media digital (literasi media digital) adalah kemampuan untuk mengakses, menganalisis, mengevaluasi, dan mengkomunikasikan isi pesan media. Dari definisi itu dipahami bahwa fokus utamanya berkaitan dengan isi pesan media. Para ahli memiliki konsep beragam terkait literasi media, McCannon mengartikan literasi media sebagai kemampuan secara efektif dan secara efisien memahami dan menggunakan komunikasi massa (Strasburger \& Wilson, 2002). Sedangkan menurut James W Potter (2005) literasi media sebagai satu perangkat perspektif di mana kita secara aktif memberdayakan diri kita sendiri dalam menafsirkan pesan-pesan yang kita terima dan bagaimana cara mengantisipasinya.

Terdapat tujuh elemen utama terkait dengan literasi media, yaitu : (1). Kesadaran akan dampak media; (2). Pemahaman proses komunikasi massa; (3). Strategi untuk menganalisis dan mendiskusikan pesan media; (4). Pemahaman tentang konten media sebagai teks yang memberi wawasan tentang budaya dan kehidupan kita; (5). Kemampuan untuk menikmati, memahami, dan menghargai konten media; (6). Pemahaman tentang kewajiban etis dan moral praktisi media; (7). Pengembangan keterampilan produksi yang tepat dan efektif. (Silverblatt, 1995; Baran, 1999: 49 - 54)

Riset yang dilakukan Bambang Mudjiyanto (2012) mengenai literasi internet dan partisipasi politik masyarakat pemilih dalam aktifitas pemanfaatan media baru menunjukkan, sebagian besar responden masih memiliki literasi internet yang rendah. Sementara mereka yang sudah memiliki literasi internet yang sedang, jumlahnya sudah cukup banyak juga. Namun, mereka yang sudah memiliki literasi internet yang tinggi, jumlahnya hampir tidak ada. Berdasarkan hasil tersebut riset pada penelitian ini ingin mengetahui bagaimana kemampuan literasi yang dimiliki oleh individu terhadap isi pesan politik yang yang bertebaran di media sosial.

\section{METODE PENELITIAN}

Paradigma yang digunakan di dalam penelitian ini adalah paradigma konstruktivisme. Paradigma konstruktivis adalah paradigma yang hampir merupakan antitesis dari paham yang meletakkan pengamatan dan objektivitas 
dalam menemukan suatu realitas atau ilmu pengetahuan. Paradigma ini memandang ilmu sosial sebagai analisis sistematis terhadap socially meaningful action melalui pengamatan langsung dan terperinci terhadap pelaku sosial yang bersangkutan menciptakan dan memelihara atau mengelola dunia sosial mereka (Hidayat, 2003:3).

Para konstruktivis juga percaya bahwa pengetahuan itu ada di dalam diri seseorang yang sedang mengetahui. Pada sebuah proses komunikasi, pesan tidak dapat dipindahkan begitu saja dari pikiran seseorang ke kepala orang lain. Penerima pesan sendirilah yang harus mengartikan apa yang telah diajarkan dengan menyesuaikan terhadap pengalaman mereka.

Konstruktivisme didefinisikan sebagai sebuah pembelajaran yang sifatnya generatif. Generatif merupakan tindakan mencipta suatu makna dari apa yang dipelajari. Konstruktivisme menyatakan bahwa apa yang dilalui dalam kehidupan selama ini, merupakan himpunan dan pembinaan pengalaman demi pengalaman. Konstruktivisme menyatakan bahwa individu menginterpretasikan dan beraksi menurut kategori konseptual dari pikiran. Realitas tidak menggambarkan diri individu, namun harus disaring melalui cara pandang orang terhadap realitas tersebut.

Secara mendasar, konstruktivisme berprinsip bahwa segala tindakan ditentukan oleh konstruk diri sekaligus juga konstruk lingkungan luar dari diri. Konstruktivisme memang merujukkan pengetahuan pada kosntruksi yang sudah ada di benak subjek. Namun, konstruktivisme juga meyakini bahwa pengetahuan bukanlah hasil sekali jadi, melainkan proses panjang sejumlah pengalaman. Ardianto dan Q Annes (2011: 154), "konstruktivisme merupakan salah satu filsafat pengetahuan yang menekankan bahwa pengetahuan individu adalah hasil konstruksi (bentukan) individu sendiri”.

Penelitian ini menggunakan metode penelitian kualitatif dengan jenis penelitian studi kasus yang menghasilkan data deskriptif yang berupa kata-kata tertulis atau lisan dari orang-orang dan perilaku yang dapat diamati. Sugiyono mendefinisikan metode penelitian kualitatif adalah metode penelitian yang digunakan untuk meneliti pada kondisi obyek yang alamiah, dimana peneliti adalah sebagai instrumen kunci, teknik pengumpulan data dilakukan secara trianggulasi (gabungan), analisis data bersifat induktif, dan hasil penelitian kualitatif lebih menekankan makna dari pada generalisasi. (Sugiyono, 2007:1). Dengan digunakan metode kualitatif, maka data yang didapat akan lebih lengkap, lebih mendalam, kredibel, dan bermakna sehingga tujuan penelitian dapat dicapai.

Adapun subjek penelitian dalam penelitian ini adalah kelompok masyarakat di lingkungan Jalan Kembang VIII Kelurahan Kwitang Jakarta Pusat, yang memiliki group WhatsAnp "basecamn kembang VU" 
Teknik Pengumpulan Data menggunakan du acara, yakni pengumpulan data primer yang menggunakan wawancara mendalam (indepth interview) dilakukan kepada subjek penelitian (Informan). Selain itu pengumpulan data Sekunder dilakukan melalui penelusuran literatur dan media. Penelitian ini menggunakan teknik pemeriksaaan keabsahan data menggunakan triangulasi sumber. Teknik triangulasi sumber dilakukan karena sumber data primer yang ditemui pada penelitian ini adalah orang-orang yang memiliki kompetensi langsung terkait penelitian. Proses pemeriksaaan keabsahan data yang dilakukan dengan cara membandingkan hasil wawancara yang dilakukan antara sumber primer dan sumber sekunder.

Penelitian ini menggunakan teknik analisis data melalui model analisis data interaktif Miles dan Huberman, dengan aktivitas sebagai berikut :

\section{Data display}

Pada tahap ini peneliti melakukan aktivitas pengumpulan data primer dengan cara melakukan wawancara mendalam dengan informan-informan.

\section{Reduction}

Setelah data-data berdasarkan hasil wawancara mendalam dengan beberapa narasumber yang dilakukan tersebut dikumpulkan dalam bentuk transkrip wawancara tahap selanjutnya adalah melakukan reduksi atau penyortiran data, dengan cara memilih hasil wawancara dan membuat mapping sesuai dengan topik kajian yang diangkat peneliti, melihat temuan-temuan yang didapat dari hasil wawancara.

\section{Conclusion drawing/ferification}

Setelah mendapatkan temuan-temuan dari hasil wawancara mendalam dan juga membuat mapping yang disesuaikan dengan topik kajian penelitian yang diangkat oleh peneliti, barulah peneliti membuat gambaran atas strategi komunikasi yang dilakukan oleh penyuluh kesehatan (Sugiyono, 2009: 244).

\section{HASIL PENELITIAN DAN PEMBAHASAN}

WhatsApp adalah aplikasi media sosial untuk berkomunikasi diantara penggunanya, komunikasi yang dapat dilakukan melalui wthatsapp dapat bersifat pribadi (personal) maupun secara kelompok (group). Pengguna WhatsApp saat ini cukup banyak dan tersebar diseluruh penjuru dunia, hal tesebut tidak terlepas juga di Indonesia. Pengguna Whatsapp di Indonesia melampaui angka yang sangat besar, menurut comscore Aplikasi WhatsApp di Indonesia mencapai angka 35,8 juta pengguna (Kompas.com).

Pengguna WhatsApp hampir menjangkau seluruh lapisan masyarakat, tidak dibatasi gender, usia, Pendidikan, pekerjaan, ataupun latar belakang lainnya. Seperti_pengouna WhatsAnp di_lingkungan Jl. Kembang VIII_Kwitang Jakarta Jurnal Avant Garde 6, No. 2, Desember 2018 
Pusat. Hampir seluruh warga yang berdomisili di lingkungan ini menggunakan aplikasi tersebut dalam keseharian mereka. Banyak group yang terbentuk yang ada di lingkungan ini, mulai dari grup remaja, karang taruna, mau pun ibu-ibu rumah tangga.

Peneliti tertarik melakukan penelitian pada masyarakat di lingkungan jalan Kembang VIII Kelurahan Kwitang Jakarta Pusat, karena kelompok warga yang tinggal dilingkungan ini sangat heterogen baik tingkat pendidikan, etnis kedaerahan, maupun pekerjaan. Lahir dan besar di Kwitang, menambah keakraban diantara warga. Mereka cukup dekat antara satu sama lain, disamping diantara mereka berteman di lingkungan tempat tinggal, merekapun berteman di sekolah yang sama. Silaturahmi yang terjalin sangat intensif diantara mereka, dari teman kecil sampai mereka dewasa. Walaupun mereka saat ini sudah berumah tangga memiliki keluarga dan bahkan diantara mereka ada yang sudah memiliki cucu, mereka selalu meluangkan waktu untuk berkumpul. Waktu yang mereka gunakan untuk berkumpul kebanyakah malam hari tepatnya setelah waktu Shalat Isya sampai tengah malam. Disamping itu kelompok ini pun saat ini memiliki grup WhatsApp dengan nama group "Community Basecamp VIII".

Grup WhatsApp "Community Basecamp VIII", dimana yang menjadi anggota kelompok ini adalah warga yang terdiri dari berbagai latar belakang. Mulai dari pekerja informal seperti tukang ojek, guru ngaji, karyawan kantoran. Dari status sosial juga kelompok ini terdiri dari warga, ketua RT, Ketua RW terdapat dua pengurus RW dalam group whatsapp community Basecamp VIII ini. Grup ini terbentuk untuk memudahkan komunikasi diantara warga yang berdomisili kembang VIII ataupun yang tadinya lahir dan besar di lingkungan kembang VIII tetapi saat ini mereka sudah tidak berdomisili lagi di Kawasan tersebut.

Karakteristik dalam Grup WhatsApp "Community Basecamp VIII". (1) Jaringan, Jaringan yang terdapat pada kelompok whatsapp ini berbentuk jaringan komunikasi bintang, komunikasi dalam jaringan ini sering juga disebut jaringan komunikasi semua saluran, sehingga setiap anggota dalam grup dapat berkomunikasi timbal balik dengan semua anggota kelompok yang lain. (2). Informasi, Arus informasi yang dihasilkan dari grup ini sangat beragam, mulai dari informasi yang santai sampai informasi yang sangat berat. (3). Arsip; (4). Interaksi, Interaksi yang terjadi adalah interaksi sosial warga kembang VIII kelurahan kwitang Jakarta Pusat, bentuk interkasi sosialnya sangat bervariasi baik secara personal maupun secara kelompok. Banyak juga interaksi yang harusnya pribadi masuk ke wilayah kelompok yang diketahui oleh para anggota kelompok lainnya.; (5). Simulasi sosial, bentuk simulasi sosial yang terjadi dalam Grup WhatsAnp ini juga sangat beragam. kadang-kadang salah satu anggota grup Jurnal Avant Garde 6, No. 2, Desember 2018 
digambarkan sebagai tokoh tertentu, untuk menghasilkan suasana yang ceria diantara anggota grup; (6). Konten, atau pesan yang menyebar di grup ini sangat beragam, banyak pesan-pesan penting yang dapat dikonsumsi oleh para anggota grup, ada juga pesan-pesan yang tidak penting bahkan pesan yang bersifat menyebarkan kebohongan juga banyak menyebar di grup ini; (7). Penyebaran.

Dari karakteristik Grup WhatsApp "Community Basecamp VIII", banyak kegiatan yang dilakukan anggota grup tersebut. Semua anggota group saling berbagi informasi untuk anggota group lainnya, banyak informasi yang mereka bagikan ada yang cukup memberi wawasan pada anggota grup. Ada juga pesan yang "membully" anggota grup lainnya sebagai bentuk candaan/joke sesama anggota, khususnya ketika anggota grup tidak ada yang menyebarkan pesan dan informasi. Selain itu banyak juga informasi yang dibagikan hanya sebagai berita bohong (hoax).

Terkait berita hoax tersebut sebagian dari anggota grup menganggap bahwa informasi tersebut benar adanya, karena pesan yang terkirim dari sumber yang mereka sangat percaya. Ada beberapa anggota grup yang mereka anggap sebagai opinion leader, jadi apa pun pesan yang disampaikan oleh opinion leader adalah berita benar. Sementara pesan yang dibagikan oleh sumber sendiri merupakan hasil copy paste dari grup lain atau pun dari sumber yang lain. Seperti yang dikemukakan oleh bapak Rofiq. Bapak Rofiq merupakan salah satu opinion leader di group basecamp kembang VIII, karena beliau merupakan salah satu pengurus masjid dilingkungan Kwitang, dan juga salah satu ustadz muda. Dari hasil wawancara dengan Bapak Rofiq didapatkan bahwa dia langsung membagikan setiap ada pesan yang masuk di aplikasi WhatsApp nya baik secara personal maupun dari group kepada anggota lainnya. "Ya, saya sering membagi pesan yang saya terima”.

Ketika ditanya lebih jauh tentang pesan yang masuk tersebut, apakah dia memahami isi pesan tersebut, informan tersebut mengatkan, "Pesan yang masuk di WA saya kadang-kadang saya baca dulu, baru saya bagikan. Kebanyakan yang saya bagikan ke grup lain tidak saya baca, langsung saya bagikan". Menurut informan kalau informasi yang dianggap penting diketahui oleh orang banyak, pesan tersebut langsung diteruskan tanpa dibaca lebih lanjut.

Menurut informan lainnya yang juga merupakan ketua RW di lingkungan tersebut, yakni Bapak Wawan, dia sering membagikan pesan tanpa dia memahami apa maksud pesan tersebut. Menurut Bapak Wawan, "Kalau saya mah, sering membagikan begitu aja, mau diteruskan lagi syukur. Gak diteruskan juga gak apa apa”. Para sumber pengirim pesan yang langsung membagikan pesan, tentunya mereka tidak memikirkan dampak yang dapat ditimbulkan dari apa yang sudah dia 
bagikan. Harusnya sumber membagikan harus memahami terlebih mereka merupakan tokoh yang diteladani oleh anggota grup lainnya.

Sebaran pesan dan informasi yang beragam tersebut menjadikan group ini sangat aktif. Pagi, siang bahkan sampai malam, sederhananya group ini 24 jam penuh dengan sebaran pesan yang beraneka ragam tersebut. Banyaknya pesan yang bertebaran dalam grup baik yang serius mau pun Disamping itu beberapa anggota grup juga sering bercanda dengan cara "membully" anggota group lainnya. Hal tersebut menjadi tambah kehangatan di dalam anggota grup.

Dalam salah satu wawancara dengan informan, didapatkan jawaban dari bapak Hendrik yang merupakan informan dari anggota grup, informan sangat menikmati segala macam informasi yang disajikan dari grup WhatsApp tersebut, dikarenakan banyak informasi yang dibagikan menambah wawasan, menghibur, dan juga mengetahui kabar lain dari setiap anggota grup. "Saya sangat senang bergabung dengan group WhatsApp basecamp kembang VIII". Menurut informan yang menarik dari grup tersebut dia mendapatkan banyak sekali informasi bahkan mampu menghibur dari setiap postingan yang disajikan dalam group tersebut. "Karena dari grup ini, saya bisa ketawa, banyak banget gambar - gambar lucu, video, bahkan pesan-pesan yang dapat memotivasi saya. Disamping itu, saya juga jadi mengetahui anggota kita sedang ngapain. Pernah juga saya mengetahui salah satu anggota group kita yang sedang di rawat dirumah sakit karena grup WA".

Masih menurut Bapak Hendrik, banyak sekali bercandaan diantara mereka yang kadang-kadang "menyakitkan" bagi mereka yang membacanya. Karena setiap candaan yang mereka lontarkan sering menggunakan kata - kata yang sangat kasar seperti mengirimkan gambar seekor binatang, kemudian gambar tersebut ditambahkan kata-kata "ini penampakan foto pak RT". Hal tersebut bagi pak Hendrik, lumrah yang terjadi di grup WA mereka.

Menurut informan lainnya, dengan adanya media sosial saat ini membantu sekali dalam bersilaturahmi dengan teman-teman masa kecilnya dahulu. "Ya saya bisa ketemu dengan teman-teman saya dari sekolah dasar, hampir lima belas tahun saya tidak ketemu dengan mereka." Roni, merupakan warga kwitang yang lahir sampai sampai menyelesaikan sekolah menengah pertama tinggal di kwitang. Saat ini memilih menetap di daerah gunung putri Bogor, sejak tergabung denga grup WhatsApp "basecampe kembang VIII", dia bisa bertemu dengan teman-temannya, bahkan saat ini Roni, hampir setiap minggu mengikuti pertemuan dengan teman-temannya di wilayah lingkungan Kwitang Jakarta Pusat.

Terkait pernyataan informan Roni, bahwa karakteristik media sosial adalah membangun dan membina jaringan sosial. Jaringan di media sosial, membentuk jaringan diantara penggunanva. Kehadiran media sosial memberikan medium bagj Jurnal Avant Garde 6, No. 2, Desember 2018 
pengguna untuk terhubung secara mekanisme teknologi. Jaringan yang terbentuk antar pengguna ini pada akhirnya membentuk komunikasi atau masyarakat yang kemudian memunculkan nilai-nilai sosial.

Bagi khalayak, mereka menganggap dengan kehadiran media sosial saat ini memberi dampak yang cukup positif bagi mereka, seperti yang di kemukakan oleh Hendrik, "iya, dengan adanya media sosial cukup memberikan dampat yang positif menurut saya, positif dalam hal menyebarkan informasi”. Sedangkan bagaimana mereka memahami konten media sebagai teks yang memberi wawasan tentang budaya dan kehidupan, informan menganggap bahwa hal tersebut sangat sesuai dan sangat ditunjang kehadiran media sosial tersebut. "adanya sosial media banyak sekali hal-hal baru yang tadinya tidak saya ketahui, ternyata banyak banget ya dalam kehidupan ini cukup bervariasi sekali”, demikian menurut Hendrik.

Banyaknya pesan yang masuk dalam group Whatsapp basecamp kembang VIII, menjadikan anggota grup dapat informas "terbaru", yang selama ini mereka tidak mengetahui informasi tersebut. Pesan yang mereka terima dianggap informasi yang layak dikomsumsi dan menjadi sesuatu yang baru bagi anggota grup, sehingga mereka terkadang tidak memahami apa maksud dari pesan yang disajikan tersebut, mereka hanya menikmati setiap ada pesan yang masuk di grup tersebut.

Kemampuan untuk menikmati, memahami, dan menghargai konten media bagi anggota grup. Dalam hal ini informan hanya dapat menikmati apa yang disajikan, sedangkan pemahaman yang mereka miliki sangat terbatas. Bahkan mereka tidak memahami hal-hal yang bisa dibagikan secara umum, ataupun konten tersebut tidak perlu di bagikan. Menurut Hendrik salah satu informan "Setiap ada kiriman gambar, video, ataupun tulisan yang masuk di grup WA, saya anggap itu merupakan informasi yang terjadi saat ini, kayak kejadian teroris tempo hari, digroup dibagikan gambar-gambar yang kelihatan semua, isi perutnya keluar, darah berceceran, pokoknya serem dah.”. Kadang-kadang mereka menikmati setiap pesan yang masuk, sementara harusnya hal-hal yang tidak layak dikonsumsi harusnya dilakukan sensor, karena menyangkut etika moral.

Kemajuan teknologi membuat setiap informasi bertebaran menghampiri masyarakat, tidak seperti media konvensional. Semakin banyaknya informasi yang ada, seharusnya masyarakat dapat memilah informasi mana informasi yang dapat mereka nikmati, mana informasi tersebut harus mereka buang. Hal tersebut sangat dibutuhkan oleh setiap individu dalam menggunakan media berbasis teknologi, khususnya media digital atau yang sering disebut media sosial. 
Terkait hal tersebut, harusnya setiap anggota group basecamp kembang viii berpikir kritis, serta kemampuan memadukan perkembangan sosial, profesional dan teknologi. Seperti yang terlihat pada tabel berikut ini :

Tabel 3. Literasi dan Kemampuan Menerima Informasi

\begin{tabular}{|l|l|}
\hline Keterangan & Kemampuan yang harus dimiliki \\
\hline Literasi teknologi & $\begin{array}{l}\text { kemampuan setiap anggota untuk memanfaatkan } \\
\text { media baru seperti internet untuk mengakses dan } \\
\text { mengomunikasikan informasi secara efektif }\end{array}$ \\
\hline Literasi informasi & $\begin{array}{l}\text { kemampuan mengumpulkan, } \\
\text { mengorganisasikan, menyaring dan mengevaluasi } \\
\text { informasi dan untuk membentuk opini yang kokoh } \\
\text { berdasarkan kemampuan tersebut }\end{array}$ \\
\hline Kreativitas media & $\begin{array}{l}\text { kapasitas individu yang terus berkembang di mana } \\
\text { pun untuk membuat dan menyebarkan konten pada } \\
\text { berbagai khalayak }\end{array}$ \\
\hline $\begin{array}{l}\text { Tanggng jawab dan } \\
\text { kompetensi sosial }\end{array}$ & $\begin{array}{l}\text { kompetensi untuk memperhitungkan akibat-akibat } \\
\text { sosial dari publikasi online dan tanggung jawab } \\
\text { terhadap anak anak }\end{array}$ \\
\hline
\end{tabular}

Sumber : Bertelsmann \&AOL Time-Warner (Dalam Iriantara, 2009:10)

Ketika informasi yang dibagikan bukan yang layak dikonsumsi publik ataupun informasi yang berupa menyebar kebencian, mengandung pornografi, ataupun bentuk kekerasan lainnya, maka individu yang menyebarkan informasi tersebut dapat dijerat dengan Undang-Undang Informasi dan Transaksi Elektronik (UU ITE). Untuk menghindari hal tersebut, maka khalayak harus cermat dan cerdik dalam bermedia sosial. Tidak harus semua informasi di sebarkan (share), tetapi harusnya di pahami dahulu (saring). Ketika individu mampu melakukan kontrol terhadap pesan-pesan yang ada di media sosial, menandakan bahwa masyarakat informasi sudah di tangan masyarakat Indonesia.

\section{SIMPULAN}

Hasil dari penelitian ini menunjukkan bahwa masyarakat memiliki pengetahuan dasar terhadap penggunaan teknologi digital; kemampuan Individu memiliki seperangkat kemampuan yang memungkinkan penggunaan dasar media. penggunaan media yang terbatas. Khalayak masyarakat mengetahui fungsi dasar dari media digital, kemampuan menggunakannya untuk tujuan tertentu dan menentukan media. Kapasitas individu untuk kritis dibarengi informasi yang diterima terbatas dan kemampuan komunikasinya melalui media juga terbatas. 
Kemampuan untuk menikmati, memahami, dan menghargai konten media bagi anggota grup. hanya dapat menikmati apa yang disajikan, sedangkan pemahaman yang mereka miliki sangat terbatas. Masih sangat rendahnya kemampuan masyarakat dalam memilih dan membedakan antara informasi yang benar dan informasi yang palsu atau "hoax". Khalayak beranggapan setiap informasi yang ada merupakan informasi yang berguna, walaupun kadang-kadang informasi tersebut adalah informasi bohong atau "hoax".

Untuk mengatasi hal tersebut literasi media sangat dibutuhkan agar masyarakat saat ini agar mereka menjadi cerdas memilih dan menyebarkan informasi. Khalayak pengguna harus fasih dalam penggunaan media, mengetahui fungsi dan manfaat media digital. Khalayak pengguna harus tahu cara mendapatkan dan melihat informasi yang dia butuhkan, serta mengevaluasi (dan meningkatkan) strategi pencarian informasi terkait politik.

Dengan adanya linterasi media masyarakat memiliki kemampuan untuk mengakses, menganalisis, mengevaluasi dan mengomunikasikan pesan, sehingga dapat memilih mana pesan media yang baik dan benar.

\section{UCAPAN TERIMA KASIH}

Warga Jalan Kembang VIII Kwitang, Jakarta Pusat

\section{DAFTAR PUSTAKA}

Ardianto, E. Q-Annes B. (2011). Filsafat Ilmu Komunikasi. Bandung.: Simbiosa Rekatama Media.

Brunner, C. \& William, T. (1999). The New Media Literacy Handbook: An Educator's Guide to Bringing New Media into the Classroom. New York: Doubleday

Buente, Wayne, dan Alice Robbin. 2008. "Trends in Internet Information Behavior: 2000-2004". Journal of the American Society for Information Science, diakses pada http://eprint.rclis.org/13679/1/ RobbinTrends2008Jun2- EntirePaper.pdf

Bus, A. G. \& Susan, B. N. (Eds.) (2009). Multimedia and Literacy Development: Improving Achievement for Young Learners. London: Routledge

European Commission 2009:Study on assessment Criteria for Media Literacy levels, brussels

Graham, P. (2006). Hypercapitalism: New Media, Languague, and Social perception of Value. New York: Peter Lang Publishing, Inc

Iriantara, Y. (2009). Literasi media apa, mengapa bagaimana.Bandung: Simbiosa Rekatama Media 
Kellner, Douglas 2010. Budaya Media: Cultural Studies, Identitas, dan Politik: Antara Modern dan Postmodern.Yokyakarta: Jalasutra.

McQuail, D. (2011). Teori Komunikasi Massa. Jakarta: Salemba Humanika

Nasrulla, R. (2013). Cyber media. Yogyakarta: idepress

Nasrulla, R. (2015). Media sosial. Bandung: Simbiosa Rekatama Media

Orange, T. \& Louise, O. F. (2007). The Media Diet for Kids. Jakarta: Serambi

Potter, W. J. (2004). Theory of Media Literacy: A Cognitive Approach. London: Sage

Potter, W. J. (2005). Media Literacy. Third Edition. London Sage

Silverblatt, A. (1995). Media Literacy: Keys to Interpreting Media Messages. London:Praeger

Sugiyono. (2007). Memahami Penelitian Kualitatif. Bandung: CV Alfabeta.

\section{JURNAL :}

Bambang Mudjiyanto (2012), Jurnal Kajian Komunikasi Vol 4, No 2 (2016) LITERASI MEDIA SEBAGAI STRATEGI KOMUNIKASI TIM SUKSES RELAWAN PEMENANGAN PEMILIHAN PRESIDEN JOKOWI JK DI BANDUNG

Annisa Senova (2016), Jurnal Studi Komunikasi dan Media Vol 16, No 1 (2012): Jurnal Studi Komunikasi dan Media Literasi Internet dan Partisipasi Politik Masyarakat Pemilih dalam Aktifitas Pemanfaatan Media Baru 